\title{
The Effect Of Problem Based Learning Model On Student's Creativity And Problem Solving Skill
}

\author{
Irawati Lebora Hutabarat \\ Physics Education Program \\ Graduate program, Universitas Negeri Medan \\ Medan, Indonesia \\ smpnegeri2tm@gmail.com
}

\author{
Nurdin Bukit \\ Physics Education Program \\ Graduate program, Universitas Negeri Medan \\ Medan, Indonesia \\ nurdinbukit5@gmail.com
}

\author{
Derlina \\ Physics Education Program \\ Graduate program, Universitas Negeri Medan \\ Medan, Indonesia \\ derlina.nst@gmail.com
}

\begin{abstract}
This study aims to analyze the creativity and problem-solving skills of students who are applied with the problem-based learning model and direct learning. This research is a quasi-experimental research with two group pre-test-posttest design. The sample of this research is taken by cluster random sampling that is as much as two classes which amounted to 64 students, experiment class consisting of 32 students who were treated with problem-based learning model and control class consist of 32 students who were treated with direct learning. The instrument used in this research is the creativity test instrument in the form of description of 7 items and the problem-solving skills in the form of description as much as 5 items. The result of analysis with t-test is the creativity of students who are treated with problem-based learning model is better than students who are treated with direct learning and problem-solving skills of students who are treated with problem-based learning model is better than students who are treated with direct learning.
\end{abstract}

Keywords—problem based learning; creativity skills; problemsolving skills

\section{INTRODUCTION}

Physics is one of the subjects in science that can be used as a tool to develop analytical and deductive thinking skills in solving problems related to natural events, both qualitatively and quantitatively using mathematics, and can develop knowledge, skills, and confidence. Physics has a definite scientific structure [1]. In fact, the process of physics learning in the class-room is more analytical, the students memorize the formula more, but they do not mean it and how the formula is used, the lecture and question and answer method is a method commonly used by the teacher in sequence explaining, giving examples, asking, exercising and assigning assignments.

The result of the research interview with the physics teacher in SMA Negeri 2 Bandar (senior high school in Indonesia) stated that in general the students' physics learning outcomes can be categorized not yet maximal, the model used during the learning process is conventional with lecture, ques- tion and answer and demonstration method causing the creativity and problem solving skills of the students to be low. The efforts to overcome these problems required changes and innovations in learning activities to improve student's problem-solving physics skills in learning that is by applying the problem based learning model.

[2] states, it is that strange we expect students to learn yet seldom teach then about learning, expect students seldom teach about problem solving" and Problem based learning is a method of teaching characterized by real problems as a context for students learning critical thinking and problemsolving skills, and acquiring knowledge. Problem based learning is a curriculum development and teaching system that develops simultaneously problem-solving strategies and knowledge and skills basics. [3] states that applying problemsolving skills in the learning process is important, because in addition to trying to answer questions or solve problems, students are also motivated to work hard. In addition to developing problem-solving skills, this approach also emphasizes the achievement of high-level competencies of critical thinking, creative, and productive.

Universally, children have different levels of creativity, some already have a high-level of creativity but some are still low. Student creativity has a considerable influence in optimizing student"s thinking process [4]. Operational creativity is defined as a process that is reflected by fluency, flexibility, and originality in thinking [5]. Creativity is an individual mental process that produces effective, imaginative, aesthetic, flexible, integration, succession, discount and effective differentiation in various ways to solve a problem [6]. Based on Joyce's teaching orientation [7], Gordon conceived four views on creativity goals: Creativity is important in daily activities, the creative process is not always mysterious, innovations are considered equally creative in all areas, creative mindset of individuals and groups is not different. The indicator of creativity used refers to [8] where the creativity aspect consists of fluency, flexible, originality, elaboration. 
[9] make the step of problem solving in science learning through five stages, visualize the problem, describe the problem in physics description, plan the solution, execute the plan, check and evaluate.

Several studies have shown the positive impact of the implementation of problem based learning models, they are [10], [11], [12], [13], [14], [15].

\section{RESEARCH METHOD}

This research was conducted in SMA Negeri 2 Bandar which is located at Marihat Bandar, Bandar district, Simalungun regency, North Sumatera province, Indonesia. The research was conducted in the second semester from March to May 2017. The sample of this study was taken two classes. Sampling is done by cluster random sampling. After the selected random sampling experimental class applied to the problem based learning model and control class applied by direct learning. This type of research uses quasi experimental methods which aims to determine whether or not from the effects or something imposed on the subject. The experimental design of quasi-experimental designs in two group pretestposttest designs such as table I.

TABLE I. CONTROL GROUP PRETEST-POSTEST DESIGN [16].

\begin{tabular}{|c|c|c|c|}
\hline Class & Pre-test & Treatment & Post-test \\
\hline Experiment & $\mathrm{Y}_{1}$ & $\mathrm{X}_{1}$ & $\mathrm{Y}_{2}$ \\
\hline Control & $\mathrm{Y}_{1}$ & $\mathrm{X}_{2}$ & $\mathrm{Y}_{2}$ \\
\hline
\end{tabular}

Creativity instrument used in the research is a matter of creativity which amounts to 7 Essay test questions based on indicators of creativity. Instruments given at the beginning and end of the study for experimental class and control class students. The lattice of creativity instruments can be seen in table II.

TABLE II. THE LATTICE OF CREATIVITY INSTRUMENTS.

\begin{tabular}{|c|c|c|}
\hline Indicator & Test & Amount \\
\hline Thinking well & 1 & 1 \\
\hline Think flexible & 2,6 & 2 \\
\hline Think original & 3,5 & 2 \\
\hline Thinking in detail & 4,7 & 2 \\
\hline Amount & & 7 \\
\hline
\end{tabular}

The test instrument of problem solving skills is used to determine the level of problem solving skills in the application of problem based learning model. The problem-solving skill instrument used in this study is a 10 problem solving skills problem on the Essay test based on the problem solving skill indicator. Instruments given at the beginning and end of the study for the experimental class and control class students. The lattice of problem-solving skills can be seen in table III.
TABLE III. THE LATTICE OF PROBLEM SOLVING SKILLS INSTRUMENTS

\begin{tabular}{|l|c|}
\hline \multicolumn{1}{|c|}{ Indicator } & \multirow{3}{*}{ Test } \\
\hline Understanding problems & \\
\cline { 1 - 1 } Interpret the problem & \\
\hline Plan the strategy & \\
\hline Implementing the strategy & \\
\hline Evaluate the solution & 10 \\
\hline Amount & \\
\hline
\end{tabular}

Data analysis techniques that calculate standard deviation, normality test using Lilliefors test, homogeneity test using variance comparison test, test the research hypothesis used data analysis technique by using t-test.

\section{RESULT AND DISCUSSION}

The results showed that students 'creativity applied with problem based learning model is better than students applied by direct learning, students' creativity has an effect on student achievement. Creativity is important for students to solve a problem in a study. In line with research [17] Creativity is important to improve problem solving skills, especially in data manipulation, controlling variables for research and to determine causal relationships in solving a problem.

The reasons that cause the creativity of students with problem-based learning model is better than the direct learning class is because students in the experimental class with the problem-based learning model is more active, creative when the process of learning direct learning and mental activity of students more courageous in solving a problem, and students are better able to create new oriental ideas.

Another cause of student creativity is better with problem based learning model according to [18] because the problembased learning model invites more students directly involved in the learning process, and on the model is given the opportunity to the students to ask the teacher about the matter that is not understood while in the control class with the student's direct learning only more listen to the explanation from the teacher, so that the students are passive in learning, then the students who in the learning is just remembering can not apply the concept in everyday life, while the student's activity is very necessary in the learning process, especially in improving student creativity.

Another cause of students' creativity is better with problem based learning model because learning is more effective class by using problem based learning model compared to direct learning class, where in class model problem based learning students are faced with problem and based on problem with model problem based learning more students have higher sense of curiosity than students in the control class. In accordance with [19].

The cause of significant student creativity between students applied to the problem-based learning model with students applied with direct learning is because students with problem-based learning more stimulate students, especially on creativity, the mindset of students with problem-based learning is more developed than the students with direct learning, so that the experimental class students are better 
able to solve the problem with various alternatives, than the control class can only solve on one alternative. The potential of students in applied with problem based learning is more improved compared with direct learning.

Problem-based learning models have a positive influence on student creativity. In accordance with [20] stated that the activity of problem based learning model is a positive influence in students' creativity because the problem-based learning model introduces a different approach of learning from the traditional method of involvement in unknown learning environment, which is acknowledged as the reason which is not only enough level of creativity but in this process, the teacher is given an opportunity in developing the division of creativity and perceptions of problem-solving abilities. Specially, student-centered learning should be used in a classroom that enables the development of student creativity.

The result of the research on students physics problem solving skills based on high, medium and low criterion was obtained in experimental class using problem based learning model in high group while control class were grouped on medium criterion, it was concluded that student problem solving skill applied with problem based model learning shows better results than students who are applied with direct learning. In line with [21], [22], [23], and [24].

The cause of problem solving skills of students with problem based learning model is better than direct learning because students in the experimental class more stimulate student creativity related to problem solving skills and students who are taught by model problem based learning more active role when learning process takes place, visible during the learning process, when students give a problem such as matter issues related to the daily life of the classroom students using the problem-based learning model more tends to find solutions problems that have been given teachers than students in the control class with and when the learning takes place or the student discussion is also more courageous to issue what is in their mind such as put forward their ideas, ask what is not understood, answer questions from the teacher and argue with teachers and argue with other students.

Another factor of problem solving skills is better students with problem based learning model because the learning experiment class is more effective because students are given on some authentic, complicated, structured problem to help students make connections between real-world theories and applications, and students try more in solving problems such as solving problems with lab work on student worksheets, different from students who apply conventional learning in a control class where the learning tends to focus on the teacher so that the students in the control class are passive. According [25] stated that the class model of problem based learning is more effective than the direct learning class.

Another factor of problem-solving skills of students with problem-based learning model is better because students of experimental class more creative have a high sense of curiosity because during the learning process students presented an authentic problem so that the ability to think increased, based on the ability of thinking students will be able to develop problem-solving skills students. According to [26] stated that class students are more creative with problem based learning model in improving their thinking ability compared to traditional class like class with direct learning

\section{CONCLUSION}

Student learning creativity who applied with problem based learning model is better than students who are taught by direct learning, based on the average score of students obtained in the experimental class of 84.22 and the control class of 70.44 and student problem-solving skills applied with problem-based learning models are better than those applied by direct learning. Based on the average score of students obtained in the experimental class of 70.57 and the control class of 60.93 .

\section{REFERENCES}

[1] Supeno. Jurnal Pembelajaran dan Pendidikan Sains (JPPS) berisi artikel yang diangkat dari hasil penelitian dan non penelitian pendidikan dan pembelajaran bidang Fisika. Jember: Program Studi Magister PendidikanIPA http://www.jurnal.unej.ac.id, 2016, Vol. 1,pp.1.

[2] Arends, R.I, "Learning to Teach.Seven editions". New York: McGrawHill, 2008.

[3] Sagala, S, “Konsep dan Makna Pembelajaran". Bandung: Alfabeta, 2011.

[4] Vahlia, I., Murdiyana \& Sutrima, "Eksperimentasi Model Pembelajaran Discovery Dan Group Investigation Terrhadap Prestasi Belajar Matematika Ditinjau dari Kreativitas Siswa”, 2013, Vol.-, pp. 191-200.

[5] Munandar, U. "Pengembangan Kreativitas Anak Berbakat". Jakarta: Rineka Cipta, 2012.

[6] Rachmawati, "Strategi Pengembangan Kreativitas Pada Anak- Usia Taman Kanak-Kanak". Jakarta : Kencana Predana Media Group, 2012.

[7] Joyce, B. Weil, Marsha \& Calhoun, E, "Models of Teaching". Yogyakarta : Pustaka Pelajar, 2009.

[8] Munandar, U. "Pengembangan Kreativitas Anak Berbakat". Jakarta: Rineka Cipta, 1995.

[9] Heller K. Heller P, "Cooperative Problem Solving in Physics A User"s Manual”. University of Minnesota, 2010.

[10] Sindelar, T, "The Effectiveness of Problem Based Learning In The School Science Classroom". Thesis. USA: Whichita State University, 2002.

[11] Yusof, Khairiyah Mohd., Aziz, Azila Abdul, "Problem Based Learning in Engineering Education: A Viable Alternative for Shaping Graduates for the 21 Century?" Conference on Engineering Education, Kuala Lumpur, 2004 Dec 14-15.

[12] Adeyemo,S, "Students"e Ability Level and Their Competence in Problem-Solving Task in Physics". International Journal of Educational Research and Technology, 2008., Vol. 1 pp. 35-47.

[13] Santyasa, I, "Pengembangan Pemahaman Konsep dan Kemampuan Pemecahan Masalah Fisika Bagi Siswa SMA Dengan Pemberdayaan Model Perubahan Konseptual Berseting Investigasi Kelompok" 2009, (Online).

[14] Panjaitan, P, "Penerapan Model Pembelajaran Berbasis Masalah (PBI) Dengan Bantuan Peta Konsep dan Sebagai Upaya Meningkatkan Pemahaman Konsep dan Pemecahan Masalah Matematika Siswa”. Thesis. Medan: PPs UNIMED, 2010.

[15] Lubis, R, H and Sahyar. "Efek Model Pembelajaran Berbasis Masalah Terhadap Hasil Belajar Siswa Pada Materi Listrik Dinamis Di Kelas X Semester II SMA Negeri 1 Hinai Kabupaten Langkat TA 2013/2014”. Jurnal Inpafi, 2014.

[16] Arikunto,S, "Dasar - Dasar Evaluasi Pendidikan". Jakarta: Bumi Aksara, 2010. 
[17] Zhakia, marpaung, r, r \& yolida, b, "Pengaruh Penerapan Model Pbl Terhadap Kreativitas Dan Keterampilan Berkomunikasi Tertulis Siswa" Jurnal Biterdidik, 2015, Vol. 3 pp.9.

[18] Ginting, E, M, Sahyar and Sihaloho, R, R, "The Effect of Problem Based Learning (PBL) Model toward Student"s Creative Thinking and Problem Solving Ability in Senior High School”. Journal of Research and Method in Education, . 2017, Vol. 7, pp.11-18.

[19] Baser, N and Ersoy, E, "The effects of problem based Learning method in higher education on creative tinking. Journal of Creative Behavior", 2013, Vol. 40 (3), pp.163-178

[20] Habeahan, Winmery, L and Sarahgih, S, "The Improving of Problem Solving Ability and Students" Creativity Mathematical by Using Problem Based Learning in SMP Negeri 2 Siantar", Journal of Educatiion and Practice, 2014, Vol. 5, pp.35

[21] Masdalipa, Mara,B, H and Derlina, "The Effect of Problem Based Learning Assisted Concept Map to Problem-Soving Ability and Critical Thingking Ability, Journal of Education and Practice, 2017, Vol.8 (19), pp.17-23.

[22] Mahrani, E, Bukit, N and Sinulingga, K, "The Effect of Problem Based Learning (PBL) Model Toward Student's Problem Solving Ability and
Critical Thingking Ability Junior High School", Journal of Research \& Method in Education, 2017, Vol.7 (5), pp.62-68.

[23] Sahyar and Fitri, R, Y, "The Effect of Problem-Based Learning Model (PBL) and Adversity Quotient (AQ) on Problem-Solving Ability", American Journal of Educational Research, . 2017. Vol. 2, pp.179-183.

[24] Temel, S, "The Effects of Problem-Based Learning on Pre-Service

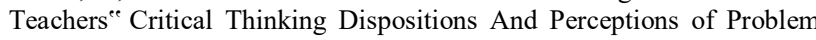
Solving Ability", South African Journal of Education, 2014, Vol. 5 (3), pp.1-20.

[25] Destianingsih, E,. Pasaribu, A,. dan Ismet, "Pengaruh model problem based learning terhadap Kemampuan pemecahan masalah siswa pada Pembelajaran fisika kelas XI di SMA Negeri 1 Tanjung Lubuk", jurnal program studi pendidikan fisika fkip universitas sriwijay, 2015, Vol-, pp.213-221.

[26] Tasoglu, K, A and Bakac, M, "The Effect of Problem Based Learning Approach on Conceptual Understanding in Teaching of Magnetism Topics” Eurasian J. Phys. \& Chem. Educ, 2014, Vol. 6 (2), pp.110-122. 